\title{
Rapid identification of Klebsiella pneumoniae isolates from various samples with biosensor and genotyping
}

\author{
Sümeyra SAVAŞ \\ The Scientific and Technological Research Council of Turkey Biosensor and Bioelectronic Group, Kocaeli, Turkey. \\ ORCID: 0000-0001-5057-9178. \\ ${ }^{\bowtie}$ Corresponding author: sumeyra.savas@tubitak.gov.tr \\ Received date: 21.05.2019- Accepted date: 05.08.2019
}

\begin{abstract}
The most important cause of Klebsiella spp. contamination of drinking water is the leakage of animal faeces into drinking water sources. Recently, the biosensor technology has quickly begun to replace other methods with its faster finding and reliability. The aim of this study was to investigate the reliability of the biosensor technology in the rapid detection of Klebsiella pneumoniae (K. pneumoniae) and to determine the presence of the relationship between $K$. pneumoniae isolates isolated from the drinking water thought to be contaminated by animal faeces and the clinical isolates. For this purpose, portable, microfluidic electrochemical sensor device version 2 (V2) was used for the detection of $K$. pneumoniae and results were confirmed with VITEK MALDI-TOF Mass Spectrometry (VITEK MS) automated system. For the molecular typing of K. pneumoniae isolates, pulsed-field gel electrophoresis (PFGE) and multiple locus variable-number tandem repeat analysis (MLVA) methods were employed and the results were compared. For these bacteria, the most appropriate typing method was tried to be determined comparatively. PFGE analysis indicated the presence of six different strains, while MLVA divided them into 23 clusters. Clonal relationships were viewed between environmental and clinical isolates. The main goal of this paper is to present, the detailed report of the comparison of the samples isolated from drinking water, animal and human faeces for K. pneumoniae. To accomplish of this goal we introduced that MLVA and PFGE methods. Also, gold nanoparticies enhanced electrochemical biosensor device is used for the determination of K. pneumoniae for the first time.
\end{abstract}

Keywords: Biosensor, K. pneumoniae, MLVA, PFGE, VITEK MS.

\section{Çeşitli örneklerden elde edilen Klebsiella pneumoniae izolatlarının biyosensör ile hızlı teşhisi ve genotiplendirilmesi}

Özet: İçme sularında Klebsiella türlerine rastlanmasının en önemli sebebi, hayvan dışkılarının içme suyu kaynaklarına sızmasıdır. Son yıllarda, biyosensör teknolojisi hızlı tespit ve güvenilirliği sayesinde diğer yöntemlerin yerini almaya başladı. Bu çalışmada biyosensör teknolojisinin Klebsiella pneumoniae (K. pneumoniae)' nin hızlı tespitindeki güvenilirliğinin belirlenmesi ve hayvan dışkısı ile kirlenmiş olduğu düşünülen içme suyundan izole edilen $K$. pneumoniae izolatları arasındaki ilişkinin varlığının tespit edilmesi amaçlandı. Bu amaçla $K$. pneumoniae izolatlarının tespiti için, portatif, mikroakışkan, elektrokimyasal biyosensör cihazı sürüm 2 (V2) kullanıldı ve sonuçlar VITEK Matriks aracılı lazer desorpsiyon/iyonizasyon-uçuş zamanlı kütle spektrometresi (VITEK MS) otomatik tanımlama sistemi ile doğrulandı. K. pneumoniae izolatlarının genotiplendirilmesinde değişken alanlı jel elektroforezi (PFGE) ve çok lokuslu değişken sayıda ardışık tekrar analizi (MLVA) yöntemleri kullanılarak sonuçlar karşıllaştırıldı. İzolatlar PFGE analizi ile 6, MLVA ile ise 23 farklı genotipe ayrıldı. Çevresel ve klinik izolatlar arasında benzer genotiplerin görüldüğ̈ belirlendi. Bu çalışmanın temel amacı; içme suyundan, hayvan ve insan dışkısından izole edilen $K$. pneumoniae örneklerinin MLVA ve PFGE yöntemi ile karşılaştırılmasıdır. Bunun ile birlikte ilk kez K. pneumoniae tayini için sinyalleri altın nanopartiküler ile güçlendirilmiş elektrokimyasal biyosensör cihazı kullanılmıştır.

Anahtar sözcükler: Biyosensör, K. pneumoniae, MLVA, PFGE, VITEK MS.

\section{Introduction}

Strains of Klebsiella pneumoniae (K. pneumoniae) have been known to be one of the most common Gramnegative pathogens causing pneumonia, septicemia, and urinary tract and soft tissue infections (4).
The detection of bacteria from drinking water is possible with several methods. From past to future with order, cultural methods, enzyme-dependent ELISA method, molecular tests such as reverse transcriptionpolymerase chain reaction, DNA hybridization and 
microarray (28). In recent years, matrix-assisted laser desorption-ionization-time of flight (MALDI-TOF MS) has emerged as a powerful technique for identification. Cultural methods have lengthy and time consuming process (27). Immunological-based methods take 3-4 h to complete (29). These test quantities of 0.1-1 ng of antigen $/ \mathrm{ml}$ can be detected. Molecular based methods need trained laboratory personnel required for the test performing VITEK MS is faster and less expensive than molecular tests, but the huge size and the high initial cost of the VITEK MS equipment are big disadvantages (27). The biosensor technology is widely used because of the advantages such as the low amount of measurable microliter range, the short time analysis (maximum 10-15 minutes), portable, rapid, no need for a trained personal, user friendly, and most importantly the low detection limit (1, 25).

The most important cause of bacterial contamination of drinking water is the leakage of animal feces into drinking water sources (13). For this reason, the detection of the source of contamination is very significant in terms of taking measures in a short time and preventing the disease. This is also possible with the choice of the most appropriate molecular typing method as much as fast detection of bacteria causing outbreaks. However, the specificity of the used method varies from microorganism to microorganism $(11,31)$.

Various molecular methods have been used in the molecular typing of $K$. pneumoniae strains (3, 8, 17). Multilocus sequence typing (MLST) method is based on DNA sequencing method and it has been found that the discriminant power and solubility are lower compared to the PFGE method $(16,19,21,22)$. Therefore, fast, easy, relatively inexpensive PCR-based Multiple Locus Variable-number Tandem Repeat Analysis (MLVA) method has been used in molecular typing.

In this study, fast, electrochemical rapid detection device V2 developed by TUBITAK/Bilgem Biosensor and Bioelectronic Group was used to determine the presence of $K$. pneumoniae in drinking water human and animal feces after cultured. The same samples were also studied with the VITEK MS automated system and the results were compared. Molecular typing methods were evaluated to determine their ability to detect clonal relationships among the isolated $K$. penumoniae strains. Until now, MLVA method was used for only several times and results are different from each other. Thus, this study is important in terms of revealing the first detailed report molecular characteristics of $K$. pneumoniae strains from environmental and clinical samples were studied with this article.

\section{Material and Methods}

Bacterial strains: Forty-nine isolates were used in the study and the distribution of them according to their origin was as follows: drinking water 19; animal stool 10; human faeces 20 (Table 1).

Detection of bacteria: Suspicious drinking water samples were passed through filter paper and then inoculated to human blood agar. After 24 hours of incubation, VITEK MS method was used to detect colonies. For electrochemical measurement, the liquid suspension formed by phosphate-buffered saline (PBS) medium was taken from the colonies grown in blood agar and adjusted to $100 \mathrm{cfu} \mathrm{mL}^{-1}$ concentration. The animal and human stool samples were stored in enrichment medium (GN broth) for 7 hours and subsequently cultivated to sheep blood agar. The VITEK MS (bioMérieux, France) measurement was performed directly from the resulting colonies while the colonies were suspended in PBS medium for electrochemical measurement at $100 \mathrm{cfu} \mathrm{mL}^{-1}$.

Development of antibody biosensor and biosensorbased electrochemical detection: Sensor chip cleaning and self-assembled monolayer (SAM) deposition were optimized in previous studies and standardized for all studies $(2,25)$. Sensor chips were prepared, vacuumpacked, and stored at $+4^{\circ} \mathrm{C}$ till use.

Table 1. General information for Klebsiella pneumoniae isolates.

\begin{tabular}{lll}
\hline Source & Location & Strain Numbers \\
\hline Faeces & IDS & ST 124, 135, 73, 96, 119, 130, 26, 85, 141, 88, 23 \\
Faeces & PS & ST 30, 11, 97, 13, 139, 129, 99 \\
Faeces & EC & ST 128, 36 \\
Water & DHM & ST 112, 21, 81, 83, 80, 50 \\
Water & PHC & ST 7, 16, 5, 136, 19, 1 113, 20, 115, 9, 102, 134, 15 \\
Cattle farm & C1-C10 & ST 90, 118, 140, 8, 138, 17, 6, 144, 75, 77 \\
\hline
\end{tabular}

IDS: Infectious Diseases Service, PS: Pediatric Service, EC: Emergency Clinic, DHM: District Health Management, PHC: Public Health Centre. 
The $200 \mathrm{~nm}$ gold-plated sensor chip surface, which was produced in accordance with the electrochemical sensor device, was immobilized with the K. pneumoniae specific monoclonal capture antibody (BioRad, USA). In previous studies, the optimized immobilization protocol was modified using K. pneumoniae specific antibody (25). First, the sensor surface was activated with EDS/NHS. The surface was then coated with $K$. pneumoniae specific monoclonal primary antibody. The sensor chip was treated with $10 \mathrm{ug} \mathrm{mL}^{-1}$ bovine serum albumin (BSA) and $1 \mathrm{M}$ ethanol was used to block the non-binding regions. The gold $(\mathrm{Au})$ chip surface was purged with PBS buffer $(\mathrm{pH}$ 7.5) between each step. The immobilized sensor chip was inserted into the electrochemical measuring device. Firstly, the water sample and then the horseradish peroxidase (HRP)-labeled secondary antibody conjugated Au nanoparticle sent to the surface of the sensor chip. Amperometric measurement was then carried out at $-0.4 \mathrm{~V}$ using 3,3', 5,5'-tetramethylbenzidine (TMB) reagents which are specific substrate for HRP enzyme. Afterwards, the $K$. pneumoniae antibody immobilized chip was measured with Salmonella spp. Shigella spp. Escherichia coli (E. coli) for the detection of cross reaction. The measurements were taken with electrochemical sensor device V2. PsTrace program was used as software for measurements (Palmsens, Netherlands).

To prepare of $\mathrm{Au}$ nanoparticles, commercially purchased $40 \mathrm{~nm}$ diameter liquid gold nanoparticles were mixed in a tube with $2.5 \mu \mathrm{HRP}$ enzyme $\left(1 \mathrm{mg} \mathrm{mL}^{-1}\right)$ and $1.5 \mu \mathrm{K}$. pneumoniae specific detection antibody (1 mg $\mathrm{mL}^{-1}$ ) and incubated for 15 minutes at room temperature in a shaker. The supernatant portion was discarded and the pellet was dissolved with $30 \mu \mathrm{lBSA}\left(10 \mathrm{mg} \mathrm{mL}^{-1}\right)$ and 70 $\mu 1$ Tris buffer $(20 \mathrm{mM})$. The prepared mixture was kept at $+4{ }^{\circ} \mathrm{C}$ until use.

VITEK MS: Bacteria identification was performed using the VITEK MS (bioMérieux, France). The card AST-N261 was used for identification of isolates. Strains direct transfer method was used for the preparation of the samples. At the end of 24-hours incubation a small amount of bacteria spread onto a single-use target slides and spread over a thin layer $1 \mu$ l matrix solution ( $\alpha$-cyano4hydroxy cinnamic acid (CHCA) matrix solution (bioMérieux, France) was added. The prepared slides were processed in the device and automatically analyzed via the MYLA software (bioMérieux, France). At the ending of the analysis, spectra were obtained (12).

Molecular typing methods: The DNA extraction method was modified (6). The isolates were grown on blood agar. Then, a single colony was taken and added in $5 \mathrm{ml}$ tryptic soy broth. After incubation at $37{ }^{\circ} \mathrm{C}$ for 20 hours, $1.5 \mathrm{ml}$ of this was taken and centrifuged at 15,000 rpm for 10 minutes. The upper liquid was discarded and $500 \mu \mathrm{l}$ of sterile distilled water was added. The boiling method was used to break down the cells and reveal the DNA. After boiling at $95{ }^{\circ} \mathrm{C}$ for 10 minutes, it was centrifuged at $15,000 \mathrm{rpm}$ for 10 minutes to remove cellular debris. After centrifugation, the upper liquid was removed and stored at $-20{ }^{\circ} \mathrm{C}$ for DNA amplification.

Eight variable number tandem repeat (VNTR) loci were amplified by multiplex polymerase chain reaction (PCR) using all of the oligo primer DNA pairs (Table 2) for MLVA (Multiple - Locus Variable Tandem Repeat) Analysis. Amplifications were performed in $50 \mu \mathrm{l}$ final reaction volume containing $2 \mathrm{mM} \mathrm{MgCl}_{2}$ (Fermantas, Germany). $0.2 \mathrm{mM}$ each of dNTPs, $10 \mathrm{pmol}$ forward

Table 2. Oligoprimers used for the amplification of VNTRs.

\begin{tabular}{|c|c|c|c|}
\hline Number of loci & $\begin{array}{l}\text { Target range } \\
\text { (Indicesin CP000647) } \\
\left(\mathrm{NC} \_009648\right)\end{array}$ & Sequence (Primers $\left(5^{\prime}-3^{\prime}\right)$ & Reference \\
\hline L1 & $153111-153861$ & $\begin{array}{l}\text { GGTGGCTCATTTTTTGGC } \\
\text { GATAAACACGCGCTAATGACC }\end{array}$ & Turton et al. (32) \\
\hline $\mathrm{L} 2$ & $287217-287244$ & $\begin{array}{l}\text { GCAGGTCTCGTCTTCATTCC } \\
\text { TGACCATCGAAGAGGCG }\end{array}$ & Turton et al. (32) \\
\hline L3 & $323741-324007$ & $\begin{array}{l}\text { GAGCTGGCGGCTGGAATA } \\
\text { GCAATCTGCCCGGAAATA }\end{array}$ & Turton et al. (32) \\
\hline $\mathrm{L} 4$ & $557947-558627$ & $\begin{array}{l}\text { AGCGTATCTGCCATTGCC } \\
\text { CAGCATGGCCAGTTTGTC }\end{array}$ & Turton et al. (32) \\
\hline L5 & 2077669-2077992 & $\begin{array}{l}\text { CCAAATCCGGGTATTTATCG } \\
\text { TTCGATACCCATCCGGAAG }\end{array}$ & Turton et al. (32) \\
\hline L6 & $4176549-4177448$ & $\begin{array}{l}\text { ATGACCAAGGAAGAACCCG } \\
\text { CTTTACCTGGCATGCGAACG }\end{array}$ & Turton et al. (32) \\
\hline L7 & $4323141-4323168$ & $\begin{array}{l}\text { CAGGATCACCGATATTTTGCG } \\
\text { GATCGGCGGCAGGTTGAG }\end{array}$ & Turton et al. (32) \\
\hline L8 & $4934720-4935748$ & $\begin{array}{l}\text { ACCGGATTAAGCGCTATTCC } \\
\text { TTCCTCGCCCACGGATAG }\end{array}$ & Turton et al. (32) \\
\hline
\end{tabular}


primer, 10 pmol reverse primer, $5 \mu 1$ template DNA, and $0.2 \mu \mathrm{l}$ Taq DNA polymerase (Fermantas, Germany). An initial denaturation cycle, for $5 \mathrm{~min} 96^{\circ} \mathrm{C}$, was followed by 30 reaction cycles, each comprising 30 s denaturation at $96{ }^{\circ} \mathrm{C}, 30$ s annealing at $60^{\circ} \mathrm{C}$, and 30 s extension at $70^{\circ} \mathrm{C}$. The reaction program ended with a final 10 min extension step at $72{ }^{\circ} \mathrm{C}$. The amplification products were run in a $2 \%$ agarose gel and their size was estimated by comparison with a DNA ladder marker (Fermantas, Germany). Amplicons were also analyzed by capillary gel electrophoresis (fragment analysis) in a Beckman-Coulter CEQ8000 sequencer. Fragment size analysis was performed using the PeakScanner software (BeckmanCoulter CEQ8000). Allele description was noted into the MLVA plug-in of the BioNumerics software (version 6 . 01, Applied Maths, Belgium).

Chromosomal DNA of the isolates was analyzed by PFGE as described (9). Chromosomes were digested in agar plugs with $\mathrm{Xba \textrm {I }}$ (Fermentas, Germany), and resulting DNA fragments were resolved in a PFGE CHEF-DR II system (Bio-Rad Laboratories, Hercules, CA) for $20 \mathrm{~h}$ at $6 \mathrm{~V} / \mathrm{cm} 2$ in $0.5 \times$ Tris-borate-EDTA buffer at $14{ }^{\circ} \mathrm{C}$. The initial and final switch times were $5 \mathrm{~s}$ and $30 \mathrm{~s}$. The banding patterns were then analyzed with BioNumerics software (Version 6.01, Applied Math, Sint-Maten-Latem, Belgium). Cluster analysis was performed by the Dice similarity coefficient and unweighted pair group method using arithmetic average (UPGMA) dendrogram (optimization $1.0 \%$, position tolerance 1.5\%). Strains were categorized as different, closely related, or indistinguishable, based on the criteria of Tenover et al. (30).

\section{Results}

Gold nanoparticle enhanced antibody sensor for $K$. pneumoniae detection: The optimum HRP concentration in the electrochemical sensor was investigated in previous studies and $12 \mathrm{ng} \mathrm{mL}^{-1} \mathrm{HRP}$ concentration was decided optimum for enhanced gold nanoparticle antibody sensor for $K$. pneumoniae detection (25). A new immobilized chip was used for each measurement with each sample. In Figure 1, the electrochemical measurements of 8 samples were overlapped and the signals between $77-155 \mathrm{nA}$ were considered as indicators of the presence of K. pneumoniae. The colony suspension prepared in $100 \mathrm{cfu} \mathrm{mL}^{-1}$ in PBS was tested individually with chips coated with Salmonella enterica, Shigella spp, E. coli and K. pneumoniae specific antibody. The same samples showed a signal between 1-5 $\mathrm{nA}$ in Salmonella enterica, Shigella spp and E.coli specific antibody coated chips. This value shows that it is not one of these microorganisms (Figure 2). The results were also studied and validated using the VITEK MS method.

Identification with VITEK MS: Strains were analyzed by the VITEK MS system. As a result, ionizable cell surface components' spectra were compared with VITEK MS biotyping software's spectra. Peaks of several samples that were selected randomly were shown in Figure 3. K. pneumoniae were identified in all samples isolated from water, human and animal by the VITEK MS automated identification system with a similarity rate of $99.9 \%$.

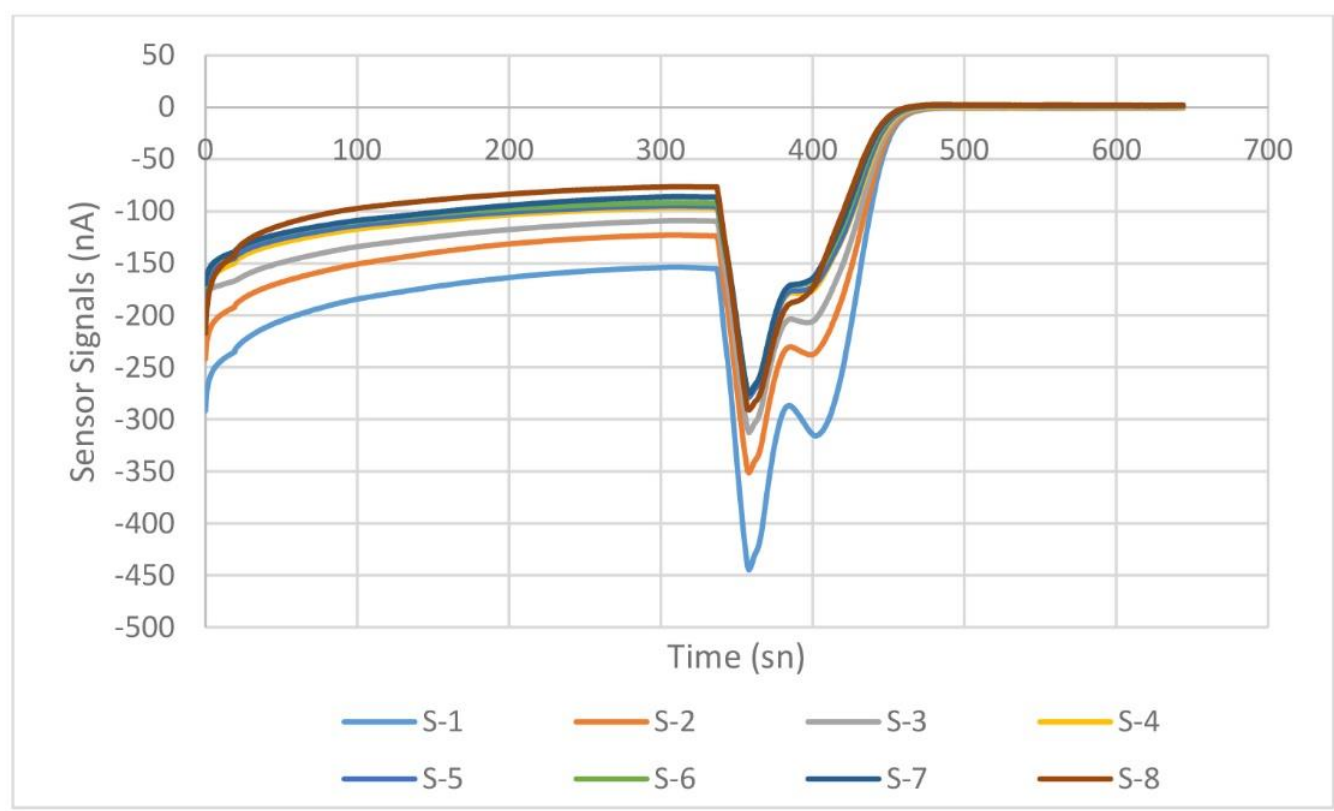

Figure 1. The electrochemical measurements of random 8 samples were overlapped and the signals were between 77-155 nA. 


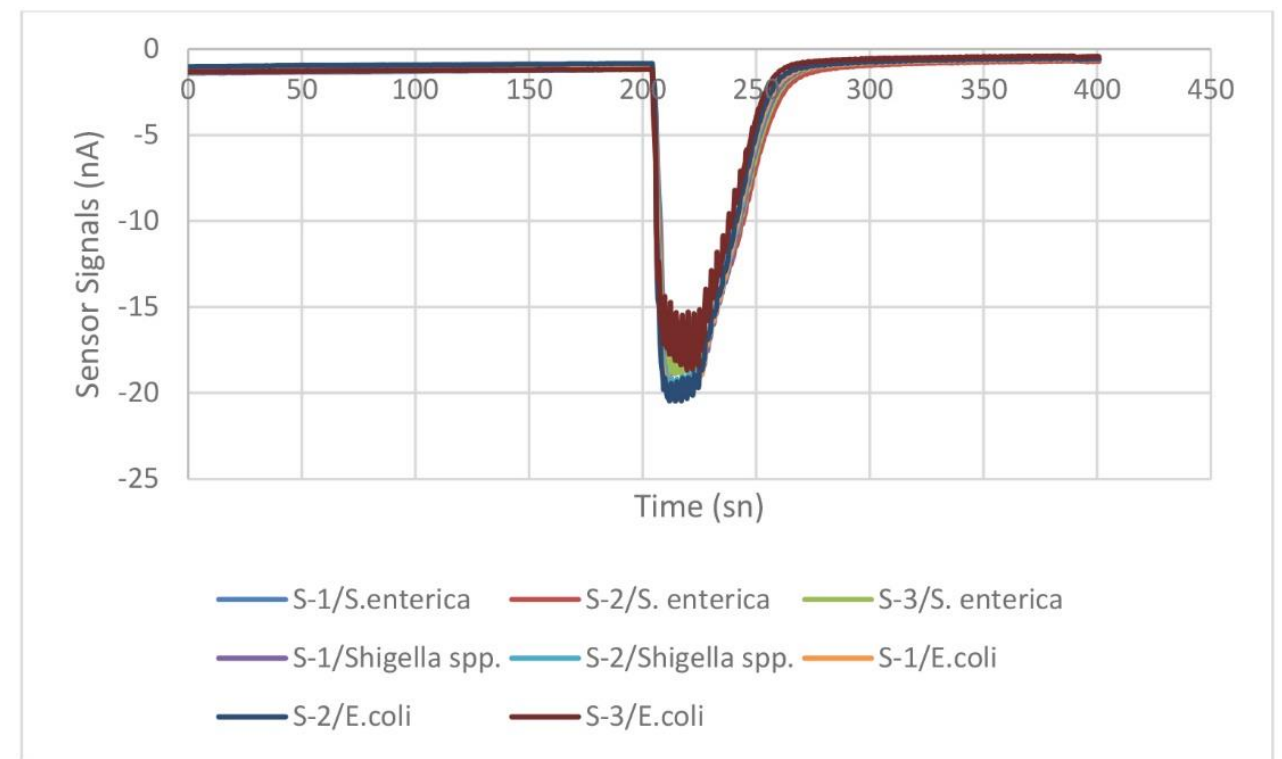

Figure 2. The same samples showed a signal between 1-5 nA in cross reaction with Salmonella enterica, Shigella spp and E.coli.

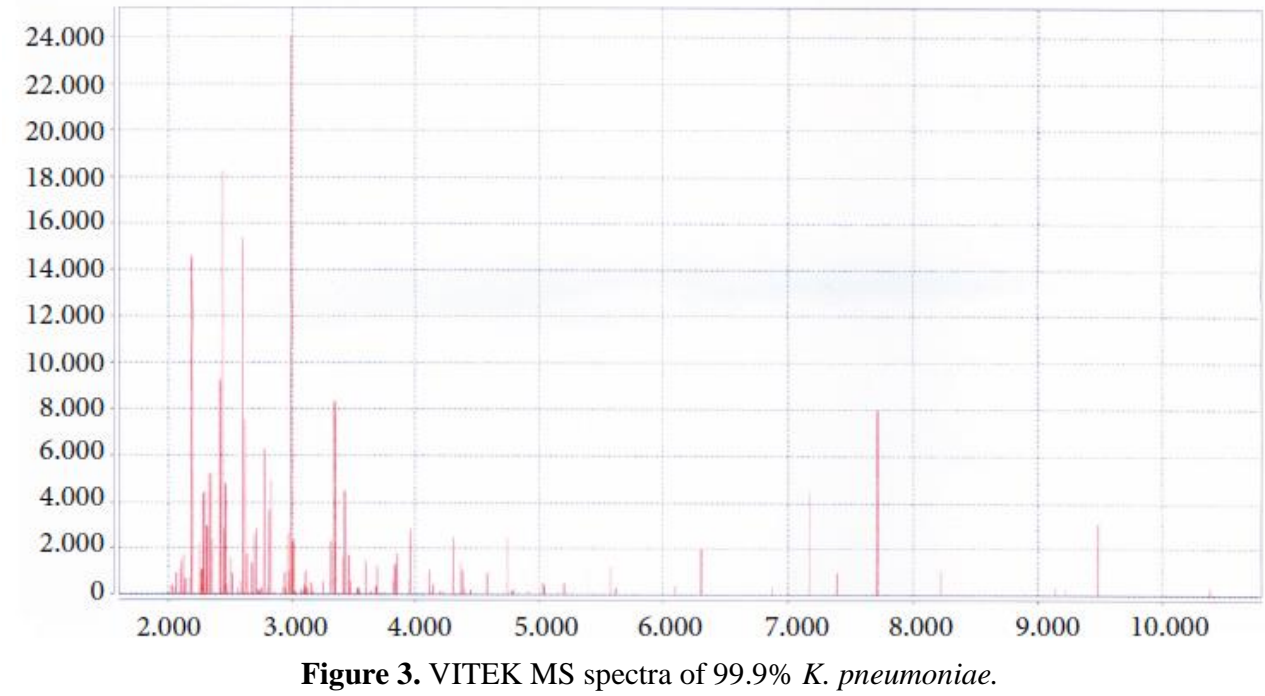

MLVA typing: Eight variable number tandem repeats distributed the 49 isolates into 23 MLVA patterns (Figure 4a). Sixteen of these patterns were represented only by a single isolate while the remaining contained between 2 and 5 members. The number of repeats found within each of the loci was also determined from the amplicon lengths and by sequencing. The number of repeats was $4.8,2.8,7.3,8.3,2.3,2.0,2.0$, and 4.5 for the eight loci, respectively.

PFGE analysis: K. pneumoniae strains produced six different PFGE pulsotypes (A-F), containing 23-25 bands following the digestion $X b a I$ restriction enzyme. These were obtained using "dice" similarity coefficient and UPGMA program (Figure 4b). The six major PFGE pulsotypes (A-F) contained 2.04\%, 36.7\%, $4.0 \%, 30.61 \%$, $2.04 \%$, and $24.4 \%$ of all the isolates, respectively. The similarity rate $(\mathrm{A}, \mathrm{B}, \mathrm{C}, \mathrm{D})$ between for pulsotype was over $95 \%$ and they were identic with each other. Pulsotype
E had only one member. Similarity within each of these five pulsotypes was higher than $90 \%$. The PFGE pattern of $\mathrm{E}$ had three fewer bands, and displayed a varying similarity to the others (A, B, C, D), ranging from $95 \%$ to $85 \%$. Pulsotype $\mathrm{F}$ was found to be unrelated to all other clusters. K. pneumoniae strains isolated from the same cattle farm at different times were grouped into the same pulsotype with the water sample isolates and some human source isolates. PFGE patterns obtained from different sources of drinking water at different time points enabled the identification of a single patient as the source of widespread infection in outpatient clinics and services. A single animal isolate (ST128) had specific MLVA and PFGE profiles and was found to be an independent subtype. In summary, the cause of $K$. pneumoniae found in the drinking water of the city was found to be a similar genotype pattern between animal and human feces and drinking water. 




a

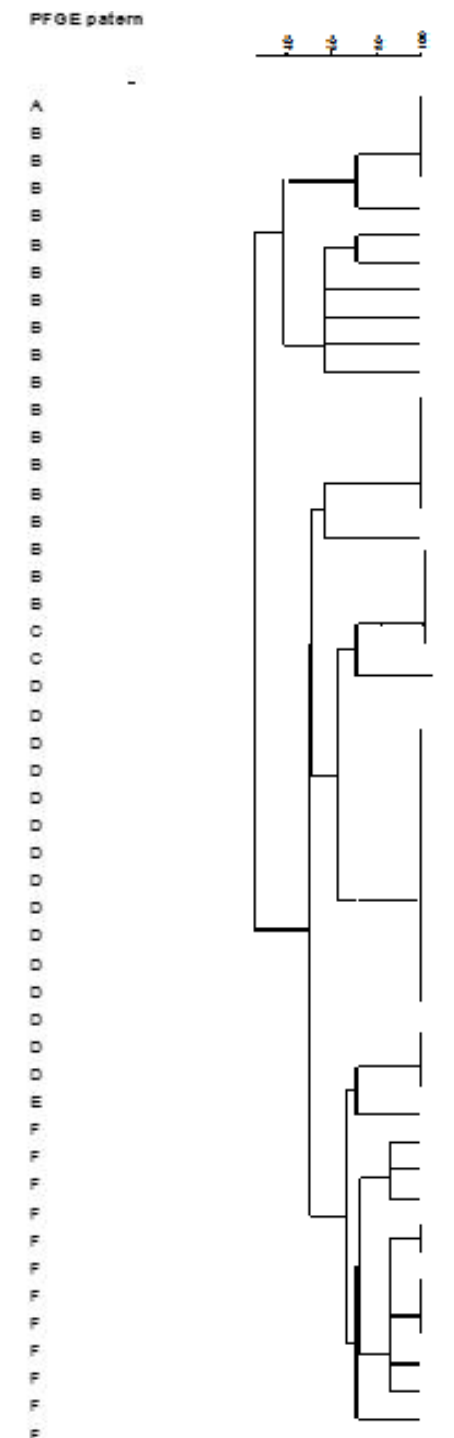



\begin{tabular}{|c|c|c|c|c|c|}
\hline I & 9 & $y$ & $ב$ & ฮ & STRAIN NUIN \\
\hline 10 & 25 & $g$ & 36 & 1 & 88 \\
\hline 10 & 25 & 9 & 36 & 1 & 112 \\
\hline 18 & 25 & 9 & 36 & 1 & 9 \\
\hline 10 & 25 & 9 & 38 & 9 & 23 \\
\hline 6 & 25 & 18 & 36 & 1 & 7 \\
\hline 8 & 25 & ${ }_{14}$ & 36 & 1 & 17 \\
\hline 8 & 25 & 24 & 36 & 1 & 102 \\
\hline 7 & 25 & 19 & 36 & 1 & 140 \\
\hline 9 & 25 & 12 & 36 & 1 & $8 s$ \\
\hline 11 & 25 & 2 & 36 & 1 & 129 \\
\hline 13 & 25 & $x$ & 36 & 1 & 21 \\
\hline 11 & 28 & $\mathrm{~g}$ & 22 & 1 & 97 \\
\hline 11 & $\mathrm{~d}$ & s & $z$ & 0 & , \\
\hline 11 & 28 & $\boldsymbol{G}$ & 22 & $=$ & 30 \\
\hline 11 & 28 & 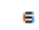 & 22 & $=$ & 99 \\
\hline 11 & 28 & E & $z 2$ & a & 8 \\
\hline 2 & 25 & 7 & 2 & 2 & 90 \\
\hline 2 & 15 & 6 & $\mathrm{n}$ & 2 & 136 \\
\hline 2 & 25 & 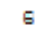 & 22 & 1 & 19 \\
\hline 2 & $\approx 5$ & E & $z$ & 1 & 134 \\
\hline 2 & 25 & $\boldsymbol{G}$ & 22 & 1 & 11 \\
\hline 23 & 25 & $a$ & $a$ & 1 & 138 \\
\hline 2 & 25 & 4 & 22 & 1 & 73 \\
\hline 2 & 25 & 4 & 22 & I & 77 \\
\hline 2 & 25 & 4 & $\mathrm{n}$ & 2 & 79 \\
\hline 2 & 25 & 4 & 22 & 2 & 16 \\
\hline 2 & $\mathrm{Ns}$ & 4 & $a$ & 4 & 141 \\
\hline 2 & 25 & 4 & 22 & 1 & 144 \\
\hline 2 & 25 & 4 & 22 & 1 & 96 \\
\hline 2 & 25 & 4 & 22 & 1 & 139 \\
\hline 2 & $2 s$ & 4 & 22 & 1 & 25 \\
\hline I & 23 & 4 & $\mathrm{n}$ & 1 & 81 \\
\hline 2 & 20 & 4 & 22 & 1 & 130 \\
\hline 2 & 23 & 4 & $a$ & 1 & 13 \\
\hline 25 & 20 & 6 & $a 2$ & 1 & 20 \\
\hline 25 & 20 & G & 22 & 1 & 113 \\
\hline 25 & 20 & G & 22 & 1 & 119 \\
\hline 25 & 20 & 6 & 22 & 1 & 124 \\
\hline$\alpha$ & 20 & 7 & 22 & 1 & 119 \\
\hline 24 & 20 & 7 & 22 & 1 & 5 \\
\hline 27 & 20 & 7 & 22 & 1 & 15 \\
\hline 22 & 20 & $G$ & 22 & 1 & 139 \\
\hline 22 & 20 & E & 22 & 1 & 118 \\
\hline 23 & 20 & 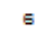 & 22 & ר & 32 \\
\hline 23 & 20 & 6 & 22 & 1 & 30 \\
\hline 23 & so & 6 & $\mathrm{M}$ & 1 & 90 \\
\hline 24 & 20 & 8 & 22 & 1 & 36 \\
\hline  & 20 & E & $a$ & 1 & 1 \\
\hline 19 & 20 & 10 & $a 2$ & 1 & 128 \\
\hline
\end{tabular}

$\mathrm{b}$

Figure 4. a) Dendogram of $K$. pneumoniae isolates showing percent similarity calculated by the Dice similarity of PFGE (XbaI) restriction endonuclease digestion, constructed using UPGMA algorithm (BioNumerics version 6.01), b) Dendrogram of MLVA results

\section{Discussion and Conclusion}

The general habitat of $K$. pneumoniae is people, animals, sewage, polluted waters and soils. Fecal contamination from human or animal is known to be the most important route to its transmission.

In the last decade, VITEK MS was developed for the identification of microorganisms (18). In the past, conventional methods and VITEK MS were compared and their results were verified by $16 \mathrm{~S}$ sequencing in the detection of isolated strains of $K$. pneumoniae from different sources. VITEK MS results were consistent with sequence results (12). Based on this study, the results obtained with VITEK MS method were compared with the results biosensors based on electrochemical sensor device V2 (TUBITAK/Bilgem) which has more reliability, more reproducibility and takes a shorter amount of time compared to other identification methods. The fact that the results are completely matched to the VITEK MS method. Therefore, it can be assumed that this device may be appropriate in cases requiring rapid detection in the field of microbiology. Sub-versions of the "electrochemical sensor machine" were used before for the detection of $E$. coli. The quantification of $E$. coli in water samples was investigated with standard and nanomaterial amplified immunoassay which resulted in LODs of $1.99 \times 10^{4} \mathrm{cfu}$ $\mathrm{mL}^{-1}$ and $50 \mathrm{cfu} \mathrm{mL}^{-1}$, respectively (2). The last V2 was used respectively for the detection of bacteria (25). Salmonella Typhimurium (S. typhimurium) was analyzed in a concentration range of $1-2.48 \times 10^{6} \mathrm{cfu} \mathrm{mL}^{-1}$ that resulted in a LOD of $12 \mathrm{cfu} \mathrm{mL}^{-1}$ using the antibody biosensor. The specificity of immunoassay was tested by studying with non-specific bacteria including $E$. coli and 
Staphylococcus aureus (S. aureus) that revealed only $2.01 \%$ and $2.66 \%$ cross-reaction. The quantification of Salmonella DNA was investigated in a concentration range of $0.002-200 \mu \mathrm{M}$ that demonstrated very high specificity and sensitivity with a LOD of $0.94 \mathrm{nM}$. Also Zhang et al. (2017) was developed a label-free DNA hybridization electrochemical sensor for the detection of $K$. pneumoniae and could detect target DNA down to $3 \times$ 10-11 M . Kumar et al., (2015) have focused on the fabricated of electrochemical biosensor for the detection of $K$. pneumoniae and detected $3.0 \times 10^{7} \mathrm{cfu} / 50 \mathrm{ml}$ in PBS. When we compare our study with these studies, it was thought that the measured limit value was lower and the applied process was easier.

Biosensor technology was used in the detection of pathogens and converted into various devices $(23,24,26)$.

There have been several studies that have employed different methods for the identification of various pathogenic bacteria. Discrimination power of these methods, at strain level, plays a crucial role in understanding the pathogen diversity and identifying the source of infection. For example, it has been reported that the discriminatory power of the PFGE method was insufficient because of the high homogeneity of the genomic structure of Bacillus anthracis strains and that MLVA differentiated the same strains with much better efficiency (34). In another study in which Acinetobacter baumannii strains have been identified by both MLVA and PFGE, comparison of the results has argued that MLVA had better discriminating power for these bacteria (11). Similar data have been produced for the typing of Staphylococcus aureus strains (16). On the other hand, MLVA and PFGE displayed similar efficiencies in the discrimination of Listeria monocytogenes strains. (31).

So far, there have been many studies on the use of MLST and PFGE molecular typing methods for $K$. pneumoniae $(15,20)$. However, the MLST method requires intensive laboratory work and it can be practiced in reference and research laboratories. The PFGE method, on the other hand, maintains its most reliable feature as gold standard method. However, the PFGE method is also time consuming and expensive to install in a laboratory. The MLVA method can be completed within 6 hours, although a standard protocol with PFGE method for typing $K$. pneumoniae takes approximately 3 days. The MLVA method, which is an established method of amplification, can be successfully applied in epidemics that develop in a short time. If infrastructure exists, confirmation of the results can be done by PFGE method. In the molecular typing of $K$. pneumoniae strains, the number of articles which compared with the PFGE method and the MLVA method was inadequate and different results were obtained. Researchers investigated the source of KPC-2-producing K. pneumoniae infections and inter-hospital spread with MLVA, MLST and PFGE methods and achieved the same results with 3 methods (20). K. pneumoniae isolates with MLVA and MLST methods and indicated that both methods have equal resolution but MLVA is more suitable for laboratory use of in terms of its low cost and labor power $(5,10)$. These studies support our work but MLST is known stronger than PFGE typing method. Despite this, The discriminant power of the PFGE method, which was studied by the MLVA and PFGE method and PFGE was much higher in the MLVA method in a study (7). However, contrary to our study, the results of both methods overlap with each other, but MLVA method has been shown to have a greater proportion of the discrimination power for $K$. pneumoniae.

When water and animal source $K$. pneumoniae samples are examined by molecular typing methods, similar types of Klebsiella isolates isolated from different sources suggests that microorganism spreading from animal source enters drinking water. There is a need for frequent control of the water network of the provincial network and the microorganisms that are rapidly spreading in the hospital and which have acquired antibiotic resistance should be controlled.

To our knowledge, this study represents the detailed report of the comparison of the samples isolated from drinking water, animal and human faeces for $K$. pneumoniae. Also, gold nanoparticle enhanced electrochemical biosensor device is used for the determination of $K$. pnemoniae for the first time and the results were compared with VITEK MS automated system. Because of its advantages such as fast detection, portable, ease of use and lack of need for experienced personnel, it is thought that this application with biosensor based electrochemical sensor device V2 may be important for microbiology laboratory and field work. In addition, genetic relationship among the strains was determined by PFGE and MLVA. This data provides better understanding of the molecular characteristics and their transmission dynamics in the city, emphasizing the need for implementation of efficient control measures for disease prevention.

\section{Acknowledgements}

We gratefully acknowledge the Biosensor and Bioelectronics Group at BILGEM-TUBITAK for the fabrication of the electrode arrays and sensor chips. Also, thank you Dr. Alper KARAGOZ and Dr. Hanifi KORKOCA for their support in collecting and analysing samples. Thank you for Duzen laboratory for VITEK MS automated system. 


\section{Conflict of Interest}

The authors declared that there is no conflict of interest.

\section{References}

1. Afonso AS, Uliana CV, Martucci DH, et al (2016): Simple and rapid fabrication of disposable carbon-based electrochemical cells using an electronic craft cutter for sensor and biosensor applications. Talanta, 146, 381-387.

2. Altintas Z, Akgun M, Kokturk G, et al (2018): A fully automated microfluidic-based electrochemical sensor for real-time bacteria detection. Biosens Bioelectron, 100, 541548.

3. Azimi L, Alaghehbandan R, Asadian M, et al (2019): Multi-drug resistant Pseudomonas aeruginosa and Klebsiella pneumoniae ciculation in a burn hospital, Tehran, Iran. GMS Hyg Infect Control, 14, ISSN 21965226.

4. Berrazeg M, Diene SM, Drissi M, et al (2013): Biotyping of multidrug- resistant Klebsiella pneumoniae clinical isolates from France and Algeria using MALDI-TOF MS. PLoS One, 8, e6142

5. Brink AATP, Von Wintersdorff CJH, Van der Donk CFM, et al (2014): Development and validation of a singletube multiple- locus variable number tandem repeat analysis for Klebsiella pneumoniae. PLoS One, 9, 3.

6. Coşkun S, Altanlar N (2012): Detection of plasmidmediated AmpC Beta-lactamase in clinical isolates of cefoxitin- resistant Escherichia coli and Klebsiella pneumoniae. Mikrobiyol Bul, 46, 375-385.

7. Derakhshan S, Najar-Peerayeh S, Bakhshi B, et al (2016): Genotyping and characterization of CTX-M-15producing Klebsiella pneumoniae isolated from an Iranian hospital. J Chemother, 28, 289-296.

8. Domokos J, Damjanova I, Kristof K, et al (2019): Multiple benefits of plasmid-mediated quinolone resistance determinants in Klebsiella pneumoniae ST11 high-risk clone and recently Emerging ST307 Clone. Front Microbiol, $12,157$.

9. Durmaz R, Otlu B, Koksal F, et al (2009): The optimization of a rapid pulsed-field gel electrophoresis protocol for the typing of Acinetobacter baumannii, Escherichia coli and Klebsiella spp. Jpn J Infect Dis, 62, 372-377.

10. Gilbert GL (2008): Using MLVA to type strains of Salmonella Typhimurium in New South Wales. NSW Public Health Bulletin, 19, 29-31.

11. Hu Y, Li B, Jin D et al (2013): Comparison of multiplelocus variable-number tandem-repeat analysis with pulsedfield gel electrophoresis typing of Acinetobacter baumannii in China. J Clin Microbiol, 51, 1263

12. Karagoz A, Acar S, Körkoca H (2015): Characterization of Klebsiella isolates by matrix-assisted laser desorption/ionization time-of-flight mass spectrometry (MALDI-TOF MS) and determination of antimicrobial resistance with VITEK 2 advanced expert system (AES). Turk J Med Sci, 45, 1335-1344.

13. Kumar D, Kumari SK (2013): Klebsiella: In drinking water. Int J Pharm Sci Invent, 12, 38-42.
14. Kumar H, Bhawana (2015): Development of electrochemical biosensor for the detection of Klebsiella pneumoniae as biological weapon. Res J Chem Sci, 5, 8897.

15. Liu J, Yu J, Chen F, et al (2018): Emergence and establishment of KPC-2-producing ST11 Klebsiella pneumoniae in a general hospital in Shanghai, China. Eur J Clin Microbiol Infect Dis, 37, 293-299.

16. Malachow N, Sabat A, Gniadkowski M, et al (2005): Comparison of multiple-locus variable-number tandemrepeat analysis with pulsed-field gel electrophoresis, spa typing, and multilocus sequence typing for clonal characterization of Staphylococcus aureus isolates. J Clin Microbiol, 43, 3095-3100.

17. Marqu C, Belas A, Aboim C, et al (2019): Evidence of Klebsiella pneumoniae sharing between healthy companion animals and co-habiting humans. J Clin Microbiol, 57, e01537-18.

18. Manji R, Bythrow M, Branda JA, et al (2014): Multicenter evaluation of the VITEK MS system for mass spectrometric identification of non-Enterobacteriaceae gram-negative bacilli. Eur J Clin Microbiol Infect Dis, 33, 337-346.

19. McDougal LK, Steward CD, Killgore GE, et al (2003): Pulsed-field gel electrophoresis typing of oxacillin-resistant Staphylococcus aureus isolates from the United States: establishing a national database. J Clin Microbiol, 41, 5113-5120.

20. Morris D, Boyle F, Morris C, et al (2012): Inter-hospital outbreak of Klebsiella pneumoniae producing KPC-2 carbapenemase in Ireland. J Antimicrob Chemother, 67, 2367-2372.

21. Mulvey MR, Chui L, Ismail J, et al (2001): Development of a Canadian standardized protocol for subtyping methicillin-resistant Staphylococcus aureus using pulsedfield gel electrophoresis. J Clin Microbiol, 39, 3481-3485.

22. Murchan S, Kaufmann ME, Deplano A, et al (2003): Harmonization of pulsed-field gel electrophoresis protocols for epidemiological typing of strains of methicillin-resistant Staphylococcus aureus: a single approach developed by consensus in 10 European laboratories and its application for tracing the spread of related strains. J Clin Microbiol, 41, 1574-1585.

23. Oliveira Marques PRB, Lermo A, Campoy S, et al (2009): Double-tagging polymerase chain reaction with a thiolated primer and electrochemical genosensing based on gold nanocomposite sensor for food safety. Anal Chem, 81, 1332-1339.

24. Ricci F, Volpe G, Micheli L, et al (2007): A review on novel developments and applications of immunosensors in food analysis. Analytica Chimica Acta, 605, 111-129.

25. Savas S, Ersoy A, Gulmez Y, et al (2018): Nanoparticle enhanced antibody and DNA biosensors for sensitive detection of Salmonella. Materials, 11, 1541.

26. Shriver-Lake LC, Erickson JS, Sapsford KE (2007): Blind laboratory trials for multiple pathogens in spiked food matrices. Anal Lett, 40, 3219-3231.

27. Singhal N, Kumar M, Kanaujia PK, et al (2015): MALDITOF mass spectrometry: an emerging technoligy for microbial identification and diagnosis. Front Microbiol, 791. 
28. Soni DK, Ahmad R, Dubey SK (2018): Biosensor for the detection of Listeria monocytogenes: emerging trends. Crit Rev in Microbiol, 44, 590-608.

29. Swaminathan B, Feng P (1994): Rapid detection of foodborne pathogenic bacteria. Annu Rev Microbiol. 48, 401426.

30. Tenover FC, Arbeit RD, Goering RV, et al (1997): How to select and interpret molecular strain typing methods for epidemiological studies of bacterial infections: a review for healthcare epidemiologists. Molecular typing working group of the society for healthcare epidemiology of America. Infect Control Hosp Epidemiol, 18, 426-439.

31. Torresi M, Acciari VA, Zennaro G, et al (2015): Comparison of multiple- locus variable number tandem repeat analysis and pulsed field gel electrophoresis in molecular subtyping of Listeria monocytogenes isolates from Italian cheese. Vet Ital, 51, 191-198.

32. Turton JF, Perry C, Elgohari S, et al (2010): $P C R$ characterization and typing of Klebsiella pneumoniae using capsular type-specific, variable number tandem repeat and virulence gene targets. J Med Microbiol, 59, 541-547.

33. Zhang Z, Yu HW, Wan GC, et al (2017): A Label-free electrochemical bipsensor based on a reduced graphene oxide and indole-5-carboxylic acid nanocomposite for the DNA detection of Klebsiella pneumoniae. J AOAC Int, 100, 548-552.

34. Zhong W, Shou Y, Yoshida TM, et al (2007): Differentiation of Bacillus anthracis, B. cereus, and B. thuringiensis by using pulsed-field gel electrophoresis. Appl Environ Microbiol, 73, 3446-3449. 